\author{
УДК 793.3:378.091.321]:78.035.2(4) \\ DOI: 10.31866/2616-7646.4.2.2021.249298
}

\title{
ПОБУДОВА УРОКУ КЛАСИЧНОГО ТАНЦЮ НА ОСНОВІ МУЗИКИ КОМПОЗИТОРІВ ВІДЕНСЬКОЇ КЛАСИЧНОЇ ШКОЛИ: ПОГЛЯД КОНЦЕРТМЕЙСТЕРА
}

\author{
Гладка Людмила Володимирівна, \\ провідний концертмейстер, \\ Київський національний університет культури і мистецтв, \\ Київ, Україна, \\ https://orcid.org/0000-0001-6932-1855, \\ glvskaukr.net
}

\begin{abstract}
Мета статті - проаналізувати музичне оформлення уроків класичного танцю та Point техніки на основі клавірної (фортепіанної) музики композиторів віденської класичної школи Й. Гайдна, В. А. Моцарта і Л. ван Бетховена. Методологія. У статті застосовано хронологічний принцип, метод аналізу та синтезу, проведено мистецтвознавчий аналіз творчості композиторів задля виявлення стильових особливостей їхніх фортепіанних сонатних циклів. Наукова новизна. Доведено, що музика трійки віденських класиків (Й. Гайдна, В. А. Моцарта, Л. ван Бетховена) якнайкраще підходить для добору музичних творів до уроків класичного танцю, Point техніки, партерного тренажу, дуетно-сценічного танцю, історико-побутового танцю. Висновки. У камерній музиці віденських класиків паралельно розвивалися дві тенденції: одна з них виходила з концепції музики як аналога світської або дружньої бесіди (твори для дилетантів, схильних отримувати насамперед задоволення від музикування, а не долати різні перепони), інша сходила до традиції ренесансної «музики для обраних» (мистецтва аристократичного та інтелектуального середовища, що цінувало вишукану складність, сміливу оригінальність та витончену гру смислів). Камерна музика писалася віденськими класиками для широкої аудиторії - пересічних сучасників і найосвіченіших меценатів, щоб мистецтво було доступним для всіх шляхетних людей. Саме тому в скарбниці клавірної музики віденських класиків можна знайти найрізноманітніші твори для формування музичної основи уроків класичного танцю та Point техніки. Цикли уроків класичного танцю та пуант-техніки на музику віденських класиків створені у творчому тандемі концертмейстера Л. Гладкої з викладачем Г. Перовою на кафедрі класичної хореографії й збережені у форматі відеозаписів. Сьогодні надзвичайно гостро постає проблема музичного виховання студентів хореографії закладів вищої освіти, яке грунтується на матеріалі зі скарбниці світової музичної класичної спадщини. Використання в музичному оформленні уроків класичного танцю, Point техніки та інших хореографічних дисциплін саме класичної музики є обов’язковою умовою формування музичного смаку й кругозору майбутніх хореографів, викладачів, балетмейстерів-постановників.
\end{abstract}

Ключові слова: класичний танець; Роint техніка; концертмейстер класу хореографії; музичне оформлення уроку хореографії; композитори віденської класичної школи. 


\section{ПОСТРОЕНИЕ УРОКА КЛАССИЧЕСКОГО ТАНЦА НА ОСНОВЕ МУЗЫКИ КОМПОЗИТОРОВ ВЕНСКОЙ КЛАССИЧЕСКОЙ ШКОЛЫ: ВЗГЛЯД КОНЦЕРТМЕЙСТЕРА}

\author{
Гладкая Людмила Владимировна, \\ ведущий концертмейстер, \\ Киевский национальный университет \\ культуры и искусств, \\ Киев, Украина, \\ https://orcid.org/0000-0001-6932-1855, \\ glvskaukr.net
}

\begin{abstract}
Цель статьи - проанализировать музыкальное оформление уроков классического танца и Point техники на основе клавирной (фортепианной) музыки композиторов венской классической школы Й. Гайдна, В. А. Моцарта и Л. ван Бетховена. Методология. В статье применен хронологический принцип, метод анализа и синтеза, произведен искусствоведческий анализ творчества композиторов для выявления стилевых особенностей фортепианных сонатных циклов каждого. Научная новизна. Доказано, что музыка тройки венских классиков (Й. Гайдна, В. А. Моцарта, Л. ван Бетховена) как нельзя лучше подходит для подбора музыкальных произведений к урокам классического танца, Point техники, партерному тренажу, дуэтно-сценическому танцу, историко-бытовому танцу. Выводы. В камерной музыке венских классиков параллельно развивались две тенденции: одна из них исходила из концепции музыки как аналога светской или дружеской беседы (произведения для дилетантов, склонных получать в первую очередь удовольствие от музицирования, а не преодолевать разные препятствия), другая восходила к ренессансной традиции «музыки для избранных» (искусства аристократической и интеллектуальной среды, которая ценила изысканную сложность, смелую оригинальность и изощренную игру смыслов). Камерная музыка писалась венскими классиками в расчете на всех - для обычных современников,
\end{abstract}

\section{CONSTRUCTION OF A CLASSICAL DANCE LESSON BASED ON THE MUSIC OF THE VIENNA CLASSICAL SCHOOL COMPOSERS: THE ACCOMPANIST'S VIEW}

\author{
Liudmyla Hladka, \\ Leading Accompanist, \\ Kyiv National University \\ of Culture and Arts, \\ Kyiv, Ukraine, \\ https://orcid.org/0000-0001-6932-1855, \\ glvsk@ukr.net
}

The purpose of the article is to analyze the musical background of classical dance lessons and Point technique based on the clavier (piano) music of the Viennese classical school composers J. Haydn, W. A. Mozart and L. van Beethoven. Research Methodology. The article uses the chronological principle, the method of analysis and synthesis; the Art history analysis of the composers' work is made to identify the stylistic features of the piano sonata cycles of each. Scientific novelty. It has been proved that the music of the three Viennese classics (J. Haydn, W. A. Mozart, L. van Beethoven) is best suited for the selection of musical works for lessons in classical dance, Point technique, ground floor training, duet-stage dance, historical and folk dance. Conclusions. Two tendencies developed in parallel in the chamber music of the Viennese classics. One of them was based on the concept of music as an analogue of secular or friendly conversation (works for amateurs who tend to enjoy music in the first place, rather than overcome various obstacles), another descended into the tradition of Renaissance 'music for the elite' (the art of the aristocratic and intellectual milieu, which valued exquisite sophistication, bold originality, and a refined play of meanings). Chamber music was written by Viennese classics for everyone - for ordinary contemporaries, and the most educated patrons of the arts so that art would be accessible to all noble people. That is why, in the treasury of clavier music of Viennese classics, you 
и для самых образованных меценатов, чтобы искусство было доступно всем благородным людям. Именно поэтому в сокровищнице клавирной музыки венских классиков можно найти самые разные произведения для формирования музыкальной основы уроков классического танца и Point техники. Циклы уроков по классическому танцу и пуант-технике на музыку венских классиков созданы в творческом тандеме концертмейстера Л. Гладкой с преподавателем Г. Перовой на кафедре классической хореографии и сохранены в формате видеозаписей. В настоящее время чрезвычайно актуальной остается проблема музыкального воспитания студентов хореографии высшего образования, основанного на материале из сокровищницы мирового музыкального классического наследия. Использование в музыкальном оформлении уроков классического танца, Point техники и других хореографических дисциплин именно классической музыки является обязательным условием формирования музыкального вкуса и кругозора будущих хореографов, преподавателей, балетмейстеров-постановщиков.

Ключевые слова: классический танеи; Point техника; концертмейстер класса хореографии; музыкальное оформление урока хореографии; композиторы венской классической школы can find a variety of works to form the musical basis of classical dance lessons and Point technique. Cycles of lessons on classical dance and pointe technique to the music of Viennese classics were created in the creative tandem of accompanist L. Hladka with teacher H. Perova at the Department of Classical Choreography were saved in video format. Currently, the musical education problem of choreography students of higher education, based on the material from the treasury of the world musical classical heritage, remains extremely urgent. The use of Point techniques and other choreographic disciplines of classical music in the musical design of classical dance lessons is a prerequisite for the formation of musical taste and outlook of future choreographers, teachers, choreographers-directors.

Keywords: classical dance; Point technique; concertmaster of the choreography class; musical design of the choreography lesson; composers of the Viennese classical school

Актуальність теми дослідження. Музика $є$ і завжди буде невід'ємним компонентом мистецької та педагогічної діяльності хореографа, обов’язковим складником навчальних і сценічних форм танцю. Вивчення та аналіз музики, представленої творами класичного репертуару, сприяє глибшому, більш об'ємному осягненню іï змісту, образності; формує усвідомлене та зріле ставлення до ролі музики в хореографії.

Мистецтво композиторів віденської класичної школи, що піднялося з верств народного життя, стало прикладом утілення глибоких думок, демократизму й витонченості, величі й простоти - класичним зразком, на який рівнялися видатні музиканти подальших епох.

Сьогодні надзвичайно гостро постає проблема музичного виховання студентів-хореографів у закладах вищої освіти. Воно має грунтуватися на матеріалі зі скарбниці світової музичної класичної спадщини, зокрема, творах віденських класиків. Ці твори повинні використовуватися в музичному оформленні уроків класичного танцю, Point техніки та інших хореографічних дисциплін, що 
$\epsilon$ обов'язковою умовою формування музичного смаку й кругозору майбутніх хореографів, викладачів танцювальних дисциплін, балетмейстерів-постановників.

Аналіз останніх досліджень та публікацій. Основним орієнтиром для наукових пошуків та методичних рекомендацій у сфері концертмейстерської діяльності в хореографії сьогодні $є$ висока професійна позиція багаторічного концертмейстера, завідувачки кафедри музичного мистецтва Академії російського балету ім. А. Я. Ваганової, докторки мистецтвознавства, авторки навчальних посібників «Концертмейстер балету» (2005), «Аналіз танцювальної і балетної музики» (2009), «Музичний аналіз в роботі педагога-хореографа» (2015), «Новий концертмейстер балету» (2016) і монографії «Музикальність класичної хореографії» (2020) - Галини Олександрівни Безуглої.

Сучасні українські дослідники концертмейстерської діяльності в хореографії $\epsilon$ концертмейстерами-практиками хореографічних класів і водночас авторами наукових розвідок. Окремі аспекти означеного питання розглянули: Л. О. Волошина «Основні принципи музичного оформлення уроку класичного танцю» (2010), О. І. Настюк «Особливості роботи концертмейстера на уроках класичного танцю» (2013), Т. О. Молчанова «Використання системно-функціонального підходу в роботі балетного концертмейстера» (2013), В. В. Зорін «Особливості організації уроку класичного танцю у вищих закладах освіти з позиції концертмейстера» (2017), Н. В. Слупська «Принципи роботи концертмейстера у класі хореографії у вищих навчальних закладах» (2017) та ін.

Зокрема, Л. О. Волошина (2010) зазначає, що роль концертмейстера на уроці класичного танцю полягає не лише в музичному оформленні вправ, але й у наданні допомоги студентам-хореографам у розвитку музичних здібностей та в набутті практичних навичок роботи 3 музичним матеріалом. «I тут викладацька роль концертмейстера виходить на перший план, тому його робота не може бути формальним виконанням музичних уривків. Музикант, як і викладач, повинен бути готовий відповісти на запитання студентів, які можуть виникнути стосовно музичного супроводу: його музичного розміру, форми, назви твору, відомостей про автора тощо» (Волошина, 2010, с. 34).

О. І. Настюк (2013) прямо вказує на те, що мистецтво танцю не може існувати без музики, «... тому з перших навчальних кроків у класах хореографії працюють два педагоги: хореограф і музикант (концертмейстер). Уроки хореографії від початку до кінця будуються на музичному матеріалі» (с. 117). Авторка статті наголошує на необхідності створення атмосфери взаєморозуміння, доброзичливості й поваги між викладачем та концертмейстером, наявності дружніх і партнерських стосунків.

Т. О. Молчанова (2012) наголошує: «3 часом структурна ієрархія музики та рухів зазнала художнього узагальнення: зміцніла тенденція зближення цих двох мистецтв, зв'язку між характером музичної інтонації та характером руху, між музичною й пластичною фразами, що сприяло формуванню співвідношення мови танцю та музики вже на новому, вищому щаблі зародження фаху концертмейстера балету» (с. 237). Вона також рекомендує використовувати на уроках класичного танцю та пуант-техніки репертуар класичної музичної спадщини. Повністю погоджуємося з ії̈ думкою про те, що музичне оформлення уроку класичного танцю, який складається з різних хореографічних комбінацій, постає своєрідною музичною сюїтою. 
В. В. Зорін (2017) головним критерієм добору музичного матеріалу вважає ступінь художньої складності музики, що виконується концертмейстером хореографічних класів: «Для підготовки студентів старших курсів слід використовувати динамічні фрагменти музики В. Моцарта, Л. Бетховена, Ф. Шопена (вальси, ноктюрни), М. Глінки, П. Чайковського» (с. 145). Також для оформлення уроків класичного танцю пропонує використовувати зразки класичної музики й інших відомих композиторів різних епох, стилів, жанрів.

Концертмейстер кафедри хореографічного мистецтва КНУКіМ Н. Слупська (2017) доносить думку, що музичний матеріал для уроків хореографії повинен складатися з найкращих зразків музичного мистецтва, а не обмежуватися примітивним музичним супроводом: «Концертмейстер хореографії несе відповідальність за виховання в студентах естетичних якостей сприйняття навколишнього світу через призму найкращих зразків музичного мистецтва» (с. 682).

Але жоден 3 авторів не вдається до аналізу побудови уроку класичного танцю на основі музики композиторів віденської класичної школи, адже вперше такі уроки було створено в Київському національному університеті культури і мистецтв (далі - КНУКіМ) концертмейстером Л. Гладкою у співпраці з викладачем Г. Перовою (цілісні уроки з класичного танцю та Point техніки на основі фортепіанної музики трійки віденських класиків - урок Point техніки на музику Й. Гайдна та уроки класичного танцю на музику В. А. Моцарта і Л. ван Бетховена в рамках хронологічного циклу уроків, починаючи з епохи Бароко (урок на музичному матеріалі прелюдій Й. С. Баха з двох томів «Добре темперованого клавіру»).

Мета статті - проаналізувати музичне оформлення уроків класичного танцю та Point техніки на основі клавірної (фортепіанної) музики композиторів віденської класичної школи Й. Гайдна, В. А. Моцарта і Л. ван Бетховена.

Виклад основного матеріалу. «Музичне мистецтво являє собою безмежну художню сферу, що дозволяє відобразити світ у звуках - від найтонших рухів людської душі до колосальних суспільних потрясінь чи природних явищ», - декларує Г. Безугла (Безуглая, 2009, с. 5). Саме тому музика посідає особливе місце в духовому житті людини, у суспільній художній діяльності, в системі мистецтв.

Близькість музики, поезії та хореографії має історичний характер: побутування цієї тріади у синкретичній єдності в давнину, в античні часи, у середньовіччі значною мірою зумовило шляхи їхньої подальшої еволюції. Упродовж тривалої історії спільного побутування, з Античності до розквіту танцю в добу Відродження, єдність музики та хореографії утверджує спорідненість засобів виразності, імпровізаційність, емоційність. Тісний взаємозв’язок музики й танцю, відображений в ритмоформулах, зберегли зразки народної музики.

Імена Йозефа Гайдна, Вольфганга Амадея Моцарта, Людвіга ван Бетховена нероздільні в нашій уяві з тими вершинами музичної культури, котрі були завойовані Європою в період першої французької революції. В історії музики їх відносять до «віденської класичної школи».

Урок Point техніки на музику клавірних сонат Йозефа Гайдна був створений у творчому тандемі з викладачкою Ганною Олексіївною Перовою, заслуженою артисткою України, доценткою кафедри класичної хореографії (згодом - кафедри хореографічного мистецтва) факультету хореографічного мистецтва КНУКіМ. Появі такого творчого уроку пуант-техніки в класичному танці на музику віденського класика передував багаторічний шлях формування концертмейстерських 
знань, умінь та навичок роботи в хореографічних класах: розуміння специфіки музичної основи для різних видів танцювальної діяльності, уявлення про основні рухи класичної хореографії, вміння передбачати логіку взаємодії музики й танцю, створювати образи руху виразовими засобами музики.

Уроки класичного танцю та Рoint техніки змогли виникнути лише в продуктивній навчально-творчій атмосфері, яка панувала на кафедрі класичної хореографії факультету хореографічного мистецтва КНУКіМ, заснованій і багато років очолюваній балетмейстеркою, народною артисткою України, професоркою, фундаторкою професійного театру сучасної хореографії «Сузір’я Аніко» Аніко Юріївною Рехвіашвілі (1963-2019).

Аніко Юріївна виховала не одне покоління талановитих хореографів, які стали викладачами, доцентами кафедри й у творчій співпраці з високопрофесійними концертмейстерами, випускницями НМАУ ім. П. І. Чайковського створили цікаві 3 художньої точки зору уроки на різних хореографічних дисциплінах: класичному танці, Point техніці, дуетно-сценічному, народно-сценічному, сучасному, історико-побутовому танці, мистецтві балетмейстера.

Урок Point техніки був задуманий в рамках хронологічного циклу уроків класичного танцю, починаючи з доби бароко і до XX ст. включно: бароко, класицизм, романтизм, імпресіонізм, експресіонізм, модернізм. Першим з циклу уроків, створених у творчій співдружності з викладачкою Г. О. Перовою, став урок на музику прелюдій Й. С. Баха 3 двох томів Добре темперованого клавіру, показаний під час Всеукраїнської науково-практичної конференції «Динаміка розвитку вищої хореографічної освіти як складової художньої культури України» (до 45-річчя заснування кафедри хореографії КНУКІМ), що проводилась у КНУКіМ 18 квітня 2015 року.

Створення таких художніх за своїм змістом уроків було б неможливе без знання педагогом-хореографом елементарної теорії музики; відомостей з аналізу музичних форм; італійської термінології, яка застосовується для позначення музичних понять; творчої співпраці й тонкого професійного взаєморозуміння 3 концертмейстером; достатньої високої хореографічної та музично-слухової, зокрема, метро-ритмічної підготовки студентів класичної кафедри КНУКіМ.

52 клавірні сонати Й. Гайдна переважно тричастинні за своєю формою, нами в процесі побудови уроку пуант-техніки були використані різні частини. Раннім сонатам композитора властиві прозора, легка фактура, перевага певного регістру (перша й друга октави), стислість форм (неповні сонатні форми), специфічна орнаментальна віртуозність (галантність і блиск епохи), наявність мелізмів (прикрас), котрі привносять у ці твори клавесинний характер. Саме тому ця музика чудово гармонує з виконанням комбінацій на пуантах.

У зрілих фортепіанних сонатах Гайдна завдяки прогресивності творчого мислення композитора сформувався новий клавірний стиль: 3'явилися мінорні тональності, форма рондо, фігури «запитання» й «відповіді» в мелодії та гармонії, орнаментальні мелодичні лінії на тлі «альбертієвих басів», хвилеподібні пожвавлення ритму, енергія ритміки пунктирних груп, яскраві модуляції, хроматичні гармонії, клавірна фактура насичувалася ломаними октавами, патетичними мінорними наростаннями й співставленнями, притаманними в подальшому й музиці В. А. Моцарта, й патетичному стилю Л. ван Бетховена.

Для пізніх клавірних сонат Гайдна показовими є дві тенденції: тенденція зростання ролі рондових форм поруч зі старою традицією гегемонії сонатної фор- 
ми, й друга тенденція - заміна тричастинності двочастинністю, тобто скорочення, стиснення сонатного циклу (здебільшого повільна перша частина та швидка друга). Ці чинники та компоненти музичної форми служать не самоціллю, а втіленням живого, тремкого руху емоцій, у якому проявляються активність поруч зі спогляданням, моменти роздумів і рішучих, енергійних стверджень, повнота та гнучкість лірики, темпераментність тональних зіставлень і колоритна гра регістрів, проростання щирості та глибини переживань через деякі умовності манер епохи.

«Озираючись знову й знову на свій життєвий шлях, Гайдн стверджувався в думці про справжню мету мистецтва: робити людей радісними та щасливими, давати їм бадьорість і силу», - зазначає Ю. Кремльов (Кремлев, 1972, с. 277). Композитор залишив світу прекрасні та безсмертні ідеали добра, любові, сердечності.

Урок класичного танцю на музичному матеріалі фортепіанних сонат В. А. Моцарта також було створено у творчій співдружності з викладачкою Г. О. Перовою.

Серед віденських класиків В. А. Моцарт з його ліричністю, людинолюбством, 3 його поетичним ставленням до образів повсякденного життя -завоював особливо задушевну, зворушливу любов у світі. Проникаючи в таємниці людської душі та розкриваючи її незліченні багатства, Моцарт у зрілі роки став одним із тих художників, які активно сприяли розкріпаченню людей від духовного гніту, накладеного суспільним устроєм, церквою та соціальною нерівністю. Моцарт своїм життям зробив рішучий крок до визволення: драматична еволюція його творчого шляху є боротьбою за свої права, за власну людську гідність, за національну незалежність.

Ліризм та любов до вокальної музики змусили композитора в перших імпровізаційних клавесинних сонатах знайти засоби, котрі б надали клавесинній мелодії співучості. Повільні частини клавірних сонат Моцарт написав наближеними за формамою до арій та пісень, а також надав «кантабельного» характеру й швидким частинам сонатного циклу. Так з'явилися відомі моцартівські «співучі алегро», в яких навіть пасажі з переливами та м'якістю схожі на вокальну колоратуру.

Ранні сонати Моцарта нагадують пустотливі імпровізації з великою кількістю витончених прикрас. Теми насичені мелізмами, фігураціями, значною кількістю тем-супутників, що супроводжують появу зв’язуючої, побічної та заключної тем, супровід - ломаними акордами та альбертієвими басами. Сонати цього періоду позначені деякою схематичністю, прямолінійністю форми, проте в них уже простежуються ознаки суто моцартівської мелодійної чарівності.

у більш пізніх сонатах композитора відчувається вплив сонатної музики Гайдна. Моцарт був закоханий у музику «татуся Гайдна» і на певному етапі намагався наслідувати її. Це підтверджує Г. Аберт (1983): «Гайдн - єдиний геній в колі друзів Моцарта міг дати йому те, що був не спроможний зробити ніхто інший: не лише мрійливу жіночу відданість, але й мужню критику, а головне - розуміння його потаємних творчих мук» (с. 20).

Моцарт почав писати сонати, коли сам жанр ще формувався, обростаючи все новими й новими знахідками. Для Бетховена фортепіанна соната стала основоположним жанром.

У подальшому Моцарт створив частини сонат у формі рухливих рондо, ця форма стала улюбленою й «коронною» в творчості композитора: каскади дивних тем, потоки дотепних думок. У деяких частинах сонат чути ритми контрдансу, менуету чи полонезу - прекрасних, ніжних танців, а також витончені «котячі» моцартівські мелодії - в яких стільки грації! «І скільки поезії! Така музика не може 
не розчулити!» (Якушина, 2005, с. 33). «Слухати Сонати Моцарта - процес виключно захопливий, але вимагає чималого інтелектуального напруження. Однак воно того варте!» (Якушина, 2005, с. 36).

Пізні сонати Моцарта були написані вже для нового інструмента - молоточкового піанофорте: в них виникли декламаційні інтонації, схожі на людську мову, основні теми почали «перемовлятися» зі своїми темами-супутниками й стали справжніми дійовими особами, що з'ясовують стосунки, але без слів. У взаємодії контрастів з’явилася театральність, поліфонічність, гармонічна розкутість, глибина почуттів, споглядальна філософічність, музика почала дихати свободою й сміливістю, підкорювати вогняним запалом.

Сонатному стилю Моцарта притаманне мислення дрібними самостійними мелодико-ритмічними одиницями, які утворюють ланцюжок мотивів, що постійно оновлюється. Кожен із них здається новим, перспективним «паростком», який здатний прорости в могутнє дерево - лише дай йому волю. Бетховен так і робив: давав волю уподобаній темі та захоплено розвивав її, деколи до повного виснаження, на межі з екстазом. Моцарт, однак, ніколи не дає волю найпрекраснішій темі: лише натякнувши на її можливості, на її невичерпний потенціал, він безжалісно кидає її та різко переключається на нову думку. Звідси - постійна недомовленість, невловимість образу.

Але моцартівські «шматки» - одиниці загального поліфонічного розвитку твору, їхня зчіпка відбувається на іншому просторовому рівні, закладеному в загальній концепції. Сам ритм зміни «шматків» виявляється впорядкованим, регулярним та утворює основний стрижень багатофігурної композиції.

Прагнення збагатити клавірний стиль запозиченням виразових прийомів оркестрової музики відобразилося й у клавірних сонатах Моцарта. Пізні сонати написані з бетховенським розмахом та міццю, в них композитор уже стояв на порозі нового фортепіанного стилю: яскраві темброві контрасти, героїка, бунтарство, скорбота, досі притаманні лише оркестру та органу, густий акордовий склад, далекий від прозорого, камерного звучання ранніх моцартівських сонат. Так композитор поклав початок драматизованої концертної трактовки жанру клавірної сонати.

Моцарта часто називають композитором «чистої музики», ніби відфільтрованої з точки зору форми, ясності викладу, визначеності в усьому, зокрема, й у втіленні емоцій, приміряючи до нього такі вивірені оціночні критерії класицизму, як квадратність, симетричність побудов, обов'язкове чергування контрастів, гладкість мелодики та голосоведіння. Проте нові дослідження та публікації свідчать, що в музиці Моцарта існує глибоко особистісне, філософське «друге дно». Його музика, за висловом I. Якушиної, «...і розумна, й гарна!» (Якушина, 2005, с. 32).

У двадцяти одній клавірній сонаті композитора партії правої та лівої руки розподілені на рівних, що свідчить про поліфонічний характер мислення Моцарта, подібно до Й. С. Баха. Для виконання творів необхідне знання стилю: індивідуального стилю Моцарта й стилю епохи.

Людяність ідеалів Моцарта, глибокий психологізм його творів, уміння опоетизувати найбуденніші явища життя, пристрасна любов до людини й безперервна думка про прекрасне майбутнє людства роблять його творіння близькими для всіх поколінь та всіх національностей.

Урок класичного танцю на музичному матеріалі фортепіанних сонат Людвіга ван Бетховена було створено у творчій співпраці з викладачкою Г. О. Перовою. 
Бетховен не мислив свої 32 сонати для фортепіано як єдиний цикл, проте в нашому сприйнятті їхня внутрішня цілісність незаперечна. Граючи та слухаючи сонати, ми проходимо разом з композитором довгий шлях від юнацьких спроб «штурмувати небеса» до містичного злиття з Богом і Космосом в останній сонаті.

Навіть для Гайдна й Моцарта жанр фортепіанної сонати не був таким значущим та не перетворився на творчу лабораторію - своєрідний щоденник потаємних вражень і переживань. Унікальність бетховенських сонат пояснюється частково й тим, що він прагнув зрівняти цей, передусім камерний, жанр з симфонією, концертом і навіть музичною драмою.

Першим сонатам, присвяченим Й. Гайдну, учнем якого він був, притаманний сміливо-полемічний та одночасно життествердний дух, мужня віртуозність. Хоча вже в ранніх сонатах Бетховена вражає глибина та проникливість повільних частин. Авторська назва єдиної програмної сонати - «Патетична» - говорить сама за себе.

Водночас композитор створив витончені мініатюри, розраховані на дівоче чи дамське виконання. У подальшій творчості ідею сонати-симфонії змінила ідея сонати-фантазії. Бетховен ніби намагається довести, що соната - це оригінальна концепція, а не застигла форма.

Бетховенські сонати експериментальні: від дивертисменту калейдоскопічних образів до трагічних монологів та діалогів, що говорять речитативами без слів; від ніжних меланхолійних акварельних тонів до похмурих інтермецо, трагічної сили настирного «мотиву долі»; від бентежної боротьби між серцем та розумом до майже шубертівської «бесіди закоханих».

Останні сонати Бетховена позначені загадковістю змісту, незвичайністю форм та граничною складністю музичної мови. У більшості з них отримала нове дихання ідея сонати-фантазії з вільно побудованим циклом і примхливим чергуванням тем. Це викликає асоціації з музикою романтиків, проте композитор залишається вірним собі: його форми завжди бездоганно вибудовані, а концепції відображають властиве йому позитивне світосприйняття. Романтичні ідеї розчарованості, неприкаяності та розбрату з навколишнім світом залишилися йому чужими.

Незважаючи на пережиті трагедії та катастрофи, ідеали добра й світла залишилися для Бетховена непорушними, а розум та воля допомогли духу перемогти страждання й земну суєту. «Герой» пізніх сонат вже не переможний воїн, а швидше творець і філософ, зброєю якого є проникаюча скрізь інтуїція та всеосяжна думка.

Фортепіанний стиль Бетховена по-органному об’ємний, по-художньому соковитий та надзвичайно вагомий. Сила тяжіння в цьому світі значно вища, ніж у світах Гайдна й Моцарта, і кожен рух вартує немалих фізичних та вольових зусиль. У ранніх сонатах Бетховена $\epsilon$, звичайно, й сторінки, написані тонко й прозоро, проте їхній загальний характер далекий від культивованої в клавірній музиці XVIII століття невимушеної витонченості, легкості та природності.

Бетховен у своїх ранніх сонатах демонстративно підриває не лише поетику тодішнього піанізму, але й устої самого жанру, постійно переступаючи всілякі формальні та стилістичні кордони, передбачені в сольній сонаті. Окрім демонстративної чотиричастинності, це й уведення в сонатний цикл скерцо чи по-моцартівськи драматично трактованого менуету, й проникнення в фортепіанну фактуру оркестрових прийомів та насичення сонатних частин безліччю по-театральному контрастних тем. Остання риса завжди була властива Моцарту з його театральним мисленням, але в молодого Бетховена вона набула навіть дещо гі- 
пертрофованого характеру: два тематичні елементи в головній партії, дві контрастні побічні теми, велика розробка, хибна реприза, віртуозна каденція.

«Надлишок ідей» проявився в ранніх сонатних циклах Бетховена і в надмірно глибоких контрастах між частинами: через яскраві тональні протиставлення, схожі на раптове перенесення в зовсім інший образно-емоційний модус. Такі зрушення, чужі для поетики Моцарта, трапляються й у Гайдна, але в Бетховена, що, безумовно, спирався на досвід попередників, вони наділяються індивідуальним сенсом.

Різкі тональні контрасти та раптові перепади настроїв між частинами камерних циклів властиві Гайдну, Моцарту властиве «дозрівання» конфлікту всередині початково неконфліктних образів та його «вихлюпування» в сполучних або розробкових розділах. Бетховен повертається до типових для ранньокласичної музики вибухів почуттів, створюючи на цій емоційній основі цілі драми з майже сюжетною інтерпретацією - так званий феномен бетховенської локальної «програмності», «характеристичності».

Панування меланхолії в повільних частинах життєрадісних чи світсько-витончених за характером циклів - ще одна риса раннього бетховенського стилю. Просвітлена меланхолія такого роду, що найбільш чітко сприймається у мінорних повільних частинах, часто переважає або присутня і в мажорних. Незважаючи на тотальну перевагу мажору в інструментальній класичній музиці добетховенського періоду, найпопулярнішими творами Гайдна й Моцарта стали згодом саме нечисленні мінорні опуси. Бетховен був схильний до занурення в мінор із перших композиторських кроків, тому мінорних циклів у нього значно більше, ніж у його двох великих попередників.

Пафос - «страва великих душ», і Бетховен у зрілих фортепіанних сонатах прирівнює суто камерний жанр вже не лише до симфонії чи концерту, але й до меси, ораторії та музичної трагедії. Роблячи цей сміливий крок, Бетховен спирався на досвід Моцарта, який ніколи не давав своїм творам програмних назв, проте наділяв камерну музику виключною глибиною, складністю та значимістю. «Небесне і земне, божественне і людське утворюють при цьому нерозривну єдність, запорукою якої є “велич відчуттів” художника» (Кириллина, 2009, с. 226).

Фортепіанні сонати Бетховена часто називають «лабораторією» його стилю. Поетика жанру сольної сонати надавала композиторові майже повну свободу. Бетховен ухопився за таку можливість із перших кроків та продовжував експериментувати з улюбленим жанром упродовж усього життя. Жанр фортепіанної сонати мав у творчості композитора автономну та дуже звивисту траєкторію розвитку, кожен з витків якої полемічно заперечував попередній - «ранній», «героїчний», «пізній» періоди, заключні строкаті сонати, в яких велетенські конструкції поєднуються з витонченими камерними диптихами.

У добетховенській музиці поєднання жанрів сонати й фантазії в межах одного циклу подекуди траплялося в Моцарта, однак при цьому фантазія, як дещо неправильне й таке, що допускає художній «безлад», завжди відігравала роль вступу власне до самої сонати (раніше - до фуги, у Баха) - твору структурно витонченого та логічно впорядкованого. У Бетховена такого розмежування немає, і фантазійна свобода поширюється на весь цикл.

Деяка оперність образів бетховенських сонат ніколи не суперечить їхній щирості, що доходить іноді до сповідальності, бо така властивість усієї класичної поетики, де автор, щоб бути зрозумілим слухачеві, часто виражав глибоко суб'єктивний зміст за допомогою звичних виразових засобів. Стилістика камерних 
жанрів XVIII століття допускала пронизливу сповідь і навіть безрадісну розв’язку, протипоказані класичній опері та симфонії. Так бувало у Моцарта, трагізм якого в деяких камерних вторах досягає жахливої безпросвітності, і навіть у скупого на відверте вираження скорботи й відчаю Гайдна. Тому Бетховен створив музику, в якій уже чути й беззахисність шубертівських мандрівників, і трагічне бунтарство героїв Ліста й Вагнера, і слізну мрійливість брамсівських інтермецо, і містичний політ майбутніх сильфід, віліс та інших стихійних духів.

Мажорні бетховенські цикли не менш індивідуальні, ніж мінорні, і кожен з них по-своєму відповідає на запити свого часу, коли «століття нинішнє і століття минуле» перебували настільки близько, що постійно стикалися одне з одним. У творчості Бетховена ці стиковки обігрувалися й ставали приводом для несподіваних знахідок та відкриттів.

У фортепіанних творах композитора галантна стилістика часто втілена в діалозі голосів, які сприймаються як «чоловічий» та «жіночий». Поетика галантності таїла в собі ідею Еросу як головного смислу й головної рушійної сили буття, що включає всі види чуттєвого та духовного тяжіння - симпатію, закоханість, пристрасть, благоговійне поклоніння, духовне прагнення до спорідненої натури, любов до Бога та Світу. «Не випадково розквіт галантного стилю збігся зі ствердженням в головах основоположної музичної максими епохи: “музика - це мова почуттів”» (Кириллина, 2009, с. 247).

Бетховенські фортепіанні сонати «героїчного» періоду за складністю, масштабністю й новизною нічим не поступаються симфоніям і концертам, а сміливістю новацій та витонченістю письма навіть перевершують їх.

Пізні сонати Бетховена завершують еволюцію класичної фортепіанної музики в усіх аспектах, зокрема, й суто інструментальному. Якщо ранні сонати Гайдна й Моцарта можна виконувати також на клавесині та клавікорді, то в Бетховена таких сонат практично немає. Бетховен вдумливо досліджував виразові можливості свого матеріалу, а оскільки об'єктивно стояв на історичному роздоріжжі, то минуле - спадок пізнього Бароко - природно межує в нього з теперішнім і майбутнім - романтичними жанрами та образами.

Ще однією особливістю пізніх сонат Бетховена $є$ асоціації містичного характеру, оскільки ця музика «не від цього світу» й відкриває нам інші духовні простори.

32 сонати Бетховена називають «Новим заповітом» фортепіанної музики на противагу «Старому заповіту» - Добре темперованому клавіру Й. С. Баха. Справді, бетховенські сонати дивляться далеко в майбутнє, не заперечуючи XVIII століття, що їх породило.

Стоячи на порозі романтичного «століття фортепіано» й розуміючи багатство технічних та звукових перспектив, що відкриваються перед композитором-піаністом, Бетховен зробив не лише ривок в майбутнє, але й підбив всеосяжний підсумок досягнень епохи, зокрема, й власних, ніби визнавши свою місію вичерпаною.

Естетичний світогляд Бетховена спирався на досить глибоку філософську концепцію, що поєднувала Бога, Природу, Людину та Мистецтво під знаком Творчості як розумної чи одухотвореної Свободи. Прогрес, «рух уперед» мислився обов’язковою умовою існування всіх цих явищ, що в цілому відповідало ідейним установкам Просвітництва. «Творчість великого художника не $є$ лише сумою деяких текстів та технічних винаходів, що в них містяться. Вона містить психограму душі, квінтесенцію особистості свого творця» (Кириллина, 2009, с. 540). 
Наукова новизна. Доведено, що музика трійки віденських класиків (Й. Гайдна, В. А. Моцарта, Л. ван Бетховена) якнайкраще підходить для добору музичних творів до уроків класичного танцю, Point техніки, партерного тренажу, дуетно-сценічного танцю, історико-побутового танцю.

Висновки. У камерній музиці віденських класиків паралельно розвивалися дві тенденції: одна 3 них виходила 3 концепції музики як аналога світської або дружньої бесіди (твори для дилетантів, схильних отримувати насамперед задоволення від музикування, а не долати різні перепони), інша сходила до традиції ренесансної «музики для обраних» (мистецтва аристократичного та інтелектуального середовища, що цінувало вишукану складність, сміливу оригінальність та витончену гру смислів).

Камерна музика писалася віденськими класиками з розрахунку на всіх -пересічних сучасників і найосвіченіших меценатів, щоб мистецтво було доступним для всіх шляхетних людей. Саме тому в скарбниці клавірної музики віденських класиків можна знайти найрізноманітніші твори для формування музичної основи уроків класичного танцю та Point техніки.

Цикли уроків з класичного танцю та пуант-техніки на музику віденських класиків, створені у творчому тандемі концертмейстера Л. Гладкої з викладачем Г. Перовою на кафедрі класичної хореографії, збережені у форматі відеозаписів.

Сьогодні надзвичайно гостро постає проблема музичного виховання студентів-хореографів у закладах вищої освіти. Воно має грунтуватися на матеріалі зі скарбниці світової музичної класичної спадщини, зокрема, творах віденських класиків. Ці твори повинні використовуватися в музичному оформленні уроків класичного танцю, Point техніки та інших хореографічних дисциплін, що $\epsilon$ обов'язковою умовою формування музичного смаку й кругозору майбутніх хореографів, викладачів танцювальних дисциплін, балетмейстерів-постановників.

\section{СПИСОК ПОСИЛАНЬ}

Аберт, Г. (1983). В. А. Моцарт (Ч. 2, кн. 1; К. К. Саква, пер.). Музыка.

Безуглая, Г. А. (2009). Анализ танцевальной и балетной музыки. Издательство Политехнического университета.

Безуглая, Г. А. (2015). Музыкальный анализ в работе педагога-хореографа. Планета музыки.

Волошина, Л. (2010). Основні принципи музичного оформлення уроку класичного танцю. Наукові записки Національного університету «Острозька академія». Серія «Психологія і педагогіка», 16, 31-40.

Зорін, В. В. (2017). Особливості організації уроку класичного танцю у вищих закладах освіти з позиції концертмейстера. Теорія та методика навчання та виховання, 43, 140-147.

Кириллина, Л. В. (2009). Бетховен: Жизнь и творчество (Т. 1-2). Московская консерватория. Кремлёв, Ю. А. (1970). Фортепианные сонаты Бетховена (2-е изд.). Советский композитор.

Кремлёв, Ю. А. (1972). Йозеф Гайдн: Очерк жизни и творчества. Музыка.

Молчанова, Т. О. (2013). Використання системно-функціонального підходу в роботі балетного концертмейстера. Актуальні проблеми історії, теорії та практики художньої культури, 31, 236-247.

Настюк, О. І. (2013). Особливості роботи концертмейстера на уроках класичного танцю. Bicник Луганського національного університету імені Тараса Шевченка. Педагогічні наукu, 10(2), 117-123. 
Новак, Л. (1973). Йозеф Гайдн: Жизнь, творчество, историческое значение (Д. Каравкина \& Вс. Розанов, пер.). Музыка.

Слупська, Н. В. (2017). Принципи роботи концертмейстера у класі хореографії у вищих навчальних закладах. Молодий вчений, 11(51), 679-684.

Якушина, И. А. (2005). Вселенная Моцарта. Музыка.

\section{REFERENCES}

Abert, H. (1983). W. A. Mozart (Pt. 2, Book 1; K. Sakva, Trans.). Muzyka [in Russian].

Bezuglaya, G. (2009). Analiz Tantseval'noi i Baletnoi Muzyki [Analysis of Dance and Ballet Music]. Polytechnic University Publishing [in Russian].

Bezuglaya, G. (2015). Muzykal'nyi Analiz v Rabote Pedagoga-Khoreografa [Musical Analysis in the Work of a Teacher-Choreographer]. Planeta Muzyki [in Russian].

Kirillina, L. (2009). Betkhoven: Zhizn'i Tvorchestvo [Beethoven: Life and Work] (Vols. 1-2). Moscow Conservatory [in Russian].

Kremlev, Yu. (1970). Fortepiannye Sonaty Betkhovena [Beethoven's Piano Sonatas] (2 $2^{\text {nd }}$ ed.). Sovetskii Kompozitor [in Russian].

Kremlev, Yu. (1972). Joseph Haydn: Ocherk Zhizni i Tvorchestva [Joseph Haydn: An Essay on Life and Work]. Muzyka [in Russian].

Molchanova, T. (2013). Vykorystannia Systemno-Funktsionalnoho Pidkhodu v Roboti Baletnoho Kontsertmeistera [Using a System-Functional Approach in the Work of a Ballet Concertmaster]. Aktualni Problemy Istorii, Teorii ta Praktyky Khudozhnoi Kultury [Topical Problems of History, Theory and Practice of Artistic Culture], 31, 236-247 [in Ukrainian].

Nastiuk, O. (2013). Osoblyvosti Roboty Kontsertmeistera na Urokakh Klasychnoho Tantsiu [Specificity of the Concertmaster of the Lessons of Classical Dance]. Visnyk Luhanskoho Natsionalnoho Universytetu imeni Tarasa Shevchenka. Pedahohichni Nauky [Bulletin of Luhansk Taras Shevchenko National University. Pedagogical Sciences], 10(2), 117-123 [in Ukrainian].

Novak, L. (1973). Joseph Haydn: Zhizn', Tvorchestvo, Istoricheskoe Znachenie [Joseph Haydn: Life, Creativity, Historical Significance] (D. Karavkina \& V. Rozanov, Trans.). Muzyka [in Russian].

Slupska, N. (2017). Pryntsypy Roboty Kontsertmeistera u Klasi Khoreohrafii u Vyshchykh Navchalnykh Zakladakh [The Principles of Work of the Concertmaster in a Choreography Class in Higher Educational Institutions]. Molodyi Vchenyi [Young Scientist], 11(51), 679684 [in Ukrainian].

Voloshyna, L. (2010). Osnovni Pryntsypy Muzychnoho Oformlennia Uroku Klasychnoho Tantsiu [Basic Principles of Musical Design of a Classical Dance Lesson]. Naukovi Zapysky Natsionalnoho Universytetu "Ostrozka Akademiia". Seriia "Psykholohiia i Pedahohika" [Scientific Notes of Ostroh Academy National University. Psychology and Pedagogy Series], 16, 31-40 [in Ukrainian].

Yakushina, I. (2005). Vselennaya Motsarta [Mozart Universe]. Muzyka [in Russian].

Zorin, V. (2017). Osoblyvosti Orhanizatsii Uroku Klasychnoho Tantsiu u Vyshchykh Zakladakh Osvity z Pozytsiii Kontsertmeistera [Features of Organization of a Classical Dance Lesson in Higher Educational Institutions from the Point of View of the Concertmaster]. Teoriia ta Metodyka Navchannia ta Vykhovannia [Theory and Methods of Teaching and Education], 43, 140-147. http://doi.org/10.5281/zenodo.1243589 [in Ukrainian]. 